\title{
Aktivitas Antibakteri Ekstrak dan Fraksi Herba Kemangi (Ocimum Sanctum L) Terhadap Staphylococcus Aureus ATCC 25923 dan Pseudomonas Aeruginosa ATCC 27853
}

\section{Antibacterial Activity of Basil (Ocimum sanctum $L$ ) Herb Extracts and Fractions Against Staphylococcus aureus ATCC 25923 and Pseudomonas aeruginosa ATCC 27853}

\author{
Taufik Turahman, Ghani Nurfiana Fadma Sari \\ Fakultas Farmasi Universitas Setia Budi Surakarta \\ JIn. Letjen Sutoyo-Mojosongo Surakarta-57127 Telp. 0271-852518 \\ email: taufikturahman@gmail.com
}

(Diterima : 2019-08-29, disetujui : 2019-11-27)

\begin{abstract}
ABSTRAK
Penyakit infeksi masih menjadi salah satu masalah kesehatan masyarakat khususnya di negara berkembang. Etiologi secara umum disebabkan oleh Staphylococcus aureus dan Pseudomonas aeruginosa. Herba kemangi (Ocimum sanctum L) merupakan tanaman yang dikenal sebagai lalapan ini memiliki khasiat sebagai antioksidan, antikanker dan antimikroba namun belum banyak informasi ilmiah sebagai antibakteri. Penelitian ini bertujuan untuk mengetahui kandungan kimia dan aktivitas antibakteri dari ekstrak etanol, fraksi n-heksan, etil asetat dan air herba kemangi terhadap pertumbuhan Staphylococcus aureus dan Pseudomonas aeruginosa secara difusi dan dilusi.

Herba kemangi diekstraksi dengan metode maserasi menggunakan etanol 96\%. Ekstrak yang diperoleh kemudian disuspensi dengan air selanjutnya difraksinasi dengan n-heksan dan etil asetat. Ekstrak herba kemangi beserta fraksi yang didapatkan selanjutnya diuji aktivitas antibakterinya dengan konsentrasi 12.5, 25 dan 50\% menggunakan metode difusi. KHM dan KBM dari fraksi teraktif diketahui menggunakan uji dilusi dengan konsentrasi $0.78,1.56,3.125$, $6.25 \%, 12.5 \%, 25 \%$ dan $50 \%$. Kontrol positif ciprofloksasin $5 \mu \mathrm{g} / 15 \mu \mathrm{l}$ dan kontrol negatif menggunakan tween 80 steril konsentrasi $5 \%$. Identifikasi golongan senyawa dilakukan dengan metode uji tabung dan kromatografi lapis tipis $(\mathrm{KLT})$.

Hasil uji aktifitas antibakteri menunjukan diameter zona hambatan pada bakteri Gram negatif secara umum lebih besar dibandingkan bakteri Gram positif. Diameter zona hambat terbesar pada bakteri Pseudomonas aeruginosa pada fraksi etil asetat herba kemangi konsentrasi $50 \%$ dengan diameter zona hambat $10 \mathrm{~mm}$, pada bakteri Staphylococcus aureus terdapat pada fraksi etil asetat pada konsentrasi 50\% memiliki daya hambat sebesar 8,6 mm. Hasil identifikasi kandungan kimia menunjukkan bahwa dalam ekstrak dan fraksi herba kemangi mengandung senyawa flavonoid, saponin steroid, dan tanin
\end{abstract}

Kata kunci: Antibakteri, Herba kemangi (Ocimum sanctum L), Staphylococcus aureus, Pseudomonas aeruginosa

\section{ABSTRACT}

Infectious disease is still one of the public health problems, especially in developing countries. Etiology is generally caused by Staphylococcus aureus and Pseudomonas aeruginosa. Basil (Ocimum sanctum L) is a plant known as lalapan which has antioxidant, anticancer and antimicrobial properties but there is not much scientific information as an antibacterial. This study aims to determine the chemical content and antibacterial activity of ethanol extract, n-hexane fraction, ethyl acetate and basil herb water on the growth of Staphylococcus aureus and Pseudomonas aeruginosa by diffusion and dilution.

Herbs are macerated using $96 \%$ ethanol. The extract obtained was then suspended with water and then fractionated with n-hexane and ethyl acetate. Basil extract and the fractions obtained were then tested for antibacterial activity at concentrations of $12.5,25$ and $50 \%$ using the diffusion method. The MIC and MBC of the most active fractions can be known using dilution 
tests with concentrations of $0.78,1.56,3.125,6.25 \%, 12.5 \%, 25 \%$ and $50 \%$. Ciprofloxacin positive control $5 \mu \mathrm{g} / 15 \mu \mathrm{l}$ and negative control using tween 80 sterile $5 \%$ concentration. Identification of groups of compounds is done by the test tube method and thin layer chromatography (TLC).

Antibacterial activity test results showed that the zone of inhibition zone in Gram-negative bacteria in general tends to be larger than Gram-positive bacteria. The largest inhibition zone diameter in the bacterium Pseudomonas aeruginosa in the ethyl acetate fraction basil concentration $50 \%$ with a diameter of inhibition zone $(10 \mathrm{~mm})$, in the Staphylococcus aureus bacteria found in the ethyl acetate fraction at a concentration of $50 \%$ has inhibitory power of $(8.6$ $\mathrm{mm}$ ). The results of the identification of the chemical content showed that the extract and fraction of basil herbs contain flavonoids, saponins steroids and tanins

Keywords: Antibacterial, Basil (Ocimum sanctum L), Staphylococcus aureus, Pseudomonas aerugino

\section{PENDAHULUAN}

Pengembangan obat di Indonesia yang berasal dari produk alam telah terbukti berhasil di masa lalu dan teknologi baru telah dikembangkan untuk memperoleh senyawa-senyawa turunan dari berbagai jenis tanaman. Kemangi, kemangen (Indonesia, Jawa) Tanaman yang banyak tumbuh di daerah tropis ini merupakan herba tegak tinggi 0,3-1,5 m. Batang pokoknya tidak jelas, berwarna hijau sering keunguan, dan berambut atau tidak. Kemangi mengandung tanin, flavonoid, alkaloid, terpenoid, saponin, glikosida, asam amino primer dan sekunder (Sarah, 2015). Berdasarkan penelitian (Atikah, 2013) yang berjudul uji aktivitas antimikroba ekstrak herba kemangi (Ocimum sanctum L) terhadap Staphylococcus aureus dan Candida albicans menyatakan bahwa ekstrak etanol $70 \%$ herba kemangi memiliki aktivitas antimikroba terhadap Staphylococcus aureus dan Candida albicans.

Berdasarkan uraian diatas, peneliti tertarik untuk meneliti golongan senyawa kimia dari herba kemangi yang aktif sebagai antibakteri, sehingga perlu dilakukan pemisahan untuk memperoleh fraksi aktif dengan kandungan senyawa lebih sederhana. Fraksi aktif diperoleh dari hasil fraksinasi menggunakan pelarut n-heksan, etilasetat dan air. Masing-masing fraksi dan ekstrak akan diuji antibakteri secara difusi dan dilusi terhadap bakteri Staphylococcus aureus ATCC 25923 dan Pseudomonas aeruginosa ATCC 27853.

\section{METODE PENELITIAN}

\section{Alat dan Bahan}

Alat yang digunakan adalah bejana maserasi, cawan porselen, moisture balance, corong pisah, evaporator, ayakan nomor 40, peralatan gelas (Pyrex), neraca analitik, lampu UV, kertas saring, lempeng KLT, tabung reaksi, cawan petri, jarum Ose, kapas lidi steril, kotak aseptis inkas, gelas ukur, batang pengaduk

Bahan yang digunakan adalah herba kemangi, etanol 96\%, n-heksan, etil asetat, aquadest, pereaksi dragendorff, Lieberman Burchard, anisaldehid, sitro borat, Media Nutrient Agar (NA), Brain Heart Infusion (BHI), dan Vogel Johnson Agar (VJA), bakteri Staphylococcus aureus ATCC 25923 dan Pseudomonas aeruginosa ATCC 27853

Pembuatan Ekstrak. Serbuk kering sebanyak 1000 gram diekstraksi 
menggunakan etanol 95\% perbandingan (1:10) dengan cara dimaserasi pada suhu kamar selama $5 \mathrm{x}$ 24 jam. Seluruh ekstrak yang didapat ditampung dan dipekatkan menggunakan rotary vacum evaporator serta disempurnakan pengeringannya di dalam oven suhu $40^{\circ} \mathrm{C}$ sehingga didapat ekstrak etanol (Crude extract) (Kemenkes RI 2013).

Pembuatan Fraksi. Sebanyak $10 \mathrm{~g}$ ekstrak etanol herba kemangi dipartisi menggunakan $75 \mathrm{ml}$ pelarut $\mathrm{n}$-heksan: $75 \mathrm{ml}$ air. Fraksinasi dengan n-heksan dilakukan sebanyak tiga kali menggunakan corong pisah. Sari nheksan selanjutnya dikumpulkan kemudian dipekatkan di vaccum evaporator, sari $n$-heksan yang sudah kental disebut fraksi n-heksan. Lapisan berair sisa dari fraksinasi dengan $\mathrm{n}$ heksan kemudian difraksinasi lagi menggunakan $75 \mathrm{ml}$ etil asetat dan dilakukan sebanyak tiga kali. Lapisan etil asetat dipisahkan dan dipekatkan dengan vaccum evaporator dan diperoleh fraksi etil asetat. Lapisan air sisa fraksinasi etil asetat dipekatkan dan disebut fraksi air (Kemenkes RI 2013)

\section{Identifikasi Kandungan Dalam} Ekstrak Dan Fraksi Herba Kemangi. Identifikasi golongan senyawa dilakukan dengan menggunakan uji tabung dan KLT. Identifikasi golongan senyawa dilakukan terhadap ekstrak dan fraksi yang diperoleh dengan melihat hasil dari penampak bercak yang bereaksi dengan reagen di antaranya: flavonoid (uap ammonia dan pereaksi sitroborat), alkaloid (pereaksi dragendroff), steroid (pereaksi liberman bourchard), tanin (pereaksi $\mathrm{FeCl}_{3}$ ), saponin (pereaksi anisaldehid) (Harborne, J. B., 1987)
Uji kualitatif ini dilakukan untuk membuktikan kebenaran bahan/zat aktif yang terkandung pada herba kemangi yang berperan dalam aktivitas antibakteri terhadap Staphylococcus aureus ATCC 25923 dan Pseudomonas aeruginosa ATCC 27853. (Novianti et.al 2014)

Pengujian Aktivitas Antibakteri. Metode difusi digunakan untuk menentukan diameter daerah hambat dari ekstrak, fraksi n-heksan, etil asetat dan air dari herba kemangi dengan konsentrasi 12.5, 25 dan 50\%. Pertama membuat suspensi bakteri yang disesuaikan dengan standar Mc Farland 0,5 dioleskan pada cawan petri yang berisi media MHA, kemudian pada setiap sumuran ditambahkan sampel menggunakan mikropipet dengan larutan ekstrak dan fraksi dari herba kemangi. Kontrol positif menggunakan antibiotik ciprofloxacin. Inkubasi dilakukan selama 24 jam pada suhu $37^{\circ}$ $\mathrm{C}$, setelah itu diukur zona hambat yang terbentuk. Pengujian tiap ekstrak dan fraksi dilakukan sebanyak 3 kali replikasi. Pengukuran zona hambat di sekitar sumuran dilakukan menggunakan jangka sorong dengan ketelitian $1 \mathrm{~mm}$.

Tahap uji antibakteri yang kedua adalah metode dilusi menggunakan beberapa pengenceran yang bertujuan untuk menentukan kadar hambat minimum KHM dan kadar bunuh minimum (KBM) terhadap bakteri $S$ aureus ATCC 25923 dan $P$ aeruginosa ATCC 27853 (Jawetz, 2007).

HASIL DAN PEMBAHASAN Hasil Ekstraksi Dan Fraksinasi

Ekstrak etanol kental yang didapatkan dari $1000 \mathrm{~g}$ serbuk adalah 
83,45 g dengan rendemen sebesar 8,34\%. Ekstraksi dilakukan dengan etanol $96 \%$ karena merupakan pelarut universal sehingga dapat mengekstraksi hampir semua kandungan kimia dalam simplisia. Ekstrak kental etanolik sebanyak $10 \mathrm{~g}$ kemudian dilakukan fraksinasi dengan $n$-heksana, etil asetat, dan air. Hasil dapat dilihat pada Tabel 1. Hasil identifikasi kandungan kimia. Analisis kandungan kimianya menggunakan metode skrining fitokimia dengan tabung reaksi dan KLT. Senyawa yang diidentifikasi merupakan senyawa yang memiliki aktivitas antibakteri yaitu alkaloid, flavonoid, steroid, dan saponin. Hasil identifikasi kandungan senyawa tersebut dapat dilihat pada Tabel 2.

Hasil Uji Aktivitas Antibakteri Dengan Metode Difusi Cakram. Hasil uji aktivitas antibakteri ekstrak dan fraksi herba kemangi dengan variasi konsentrasi 50, 25 dan 12,5\%, dengan tiga kali replikasi setelah diinkubasi selama 24 jam pada suhu $37^{\circ} \mathrm{C}$ memiliki respon yang bervariasi berkisar 7-10 $\mathrm{mm}$. respon zona hambat dapat dikategorikan lemah sampai sedang yaitu $<11 \mathrm{~mm}$. Menurut (Riska dkk
2014). Kontrol positif ciprofloxacin konsentrasi $5 \mu \mathrm{g}$ menunjukkan adanya aktivitas antibakteri yang ditandai dengan adanya zona hambat dengan diameter zona hambat rata-rata $26 \mathrm{~mm}$ pada $S$ aureus ATCC 25923 dan $28 \mathrm{~mm}$ pada $P$ aeruginosa ATCC 27853 sehingga respon zona hambat pada kontrol positif dapat dikategorikan sangat kuat. Hasil dapat dilihat pada Tabel 3 dan Gambar 1.

Hasil pengujian difusi yang telah dilakukan menunjukan diameter zona hambat pada bakteri Gram negatif secara umum cendrung lebih besar dibandingkan bakteri Gram positif, diameter zona hambat terbesar pada bakteri Pseudomonas aeruginosa ATCC 27853. terdapat pada fraksi etil asetat pada konsentrasi $50 \%$ dengan diameter zona hambat $10 \mathrm{~mm}$. untuk bakteri Gram positif Staphylococcus aureus ATCC 25923 terdapat pada fraksi etil asetat dan ekstrak dengan konsentrasi $50 \%$ memiliki zona hambat sebesar $(8,6$ $\mathrm{mm})$. Hal tersebut menunjukan bahwa bakteri Gram negatif lebih rentan oleh senyawa pada ekstrak dan fraksi herba kemangi dibandingkan bakteri Gram positif.

\section{Tabel 1. Hasil fraksinasi ekstrak etanol herba kemangi}

\begin{tabular}{cccc}
\hline Pelarut & Ekstrak $\mathbf{( g )}$ & Berat fraksi $\mathbf{( g )}$ & Rendemen (\%) \\
\hline n-heksan & 30 & 7,12 & 23,7 \\
etil asetat & 113,52 & 9,82 & 32,7 \\
air & 121,78 & 12,56 & 41,8 \\
\hline
\end{tabular}

Tabel 2. Hasil identifikasi senyawa setiap fraksi dari ekstrak herba kemangi

\begin{tabular}{cccccc}
\hline Uji & Alkaloid & Flavonoid & Steroid & Saponin & Tanin \\
\hline ekstrak & - & + & + & - & + \\
$n$-heksan & - & - & + & - & - \\
etil asetat & - & + & + & - & + \\
air & - & + & - & + & - \\
\hline
\end{tabular}


Tabel 3. Rata-rata diameter zona hambat yang dihasilkan ekstrak.

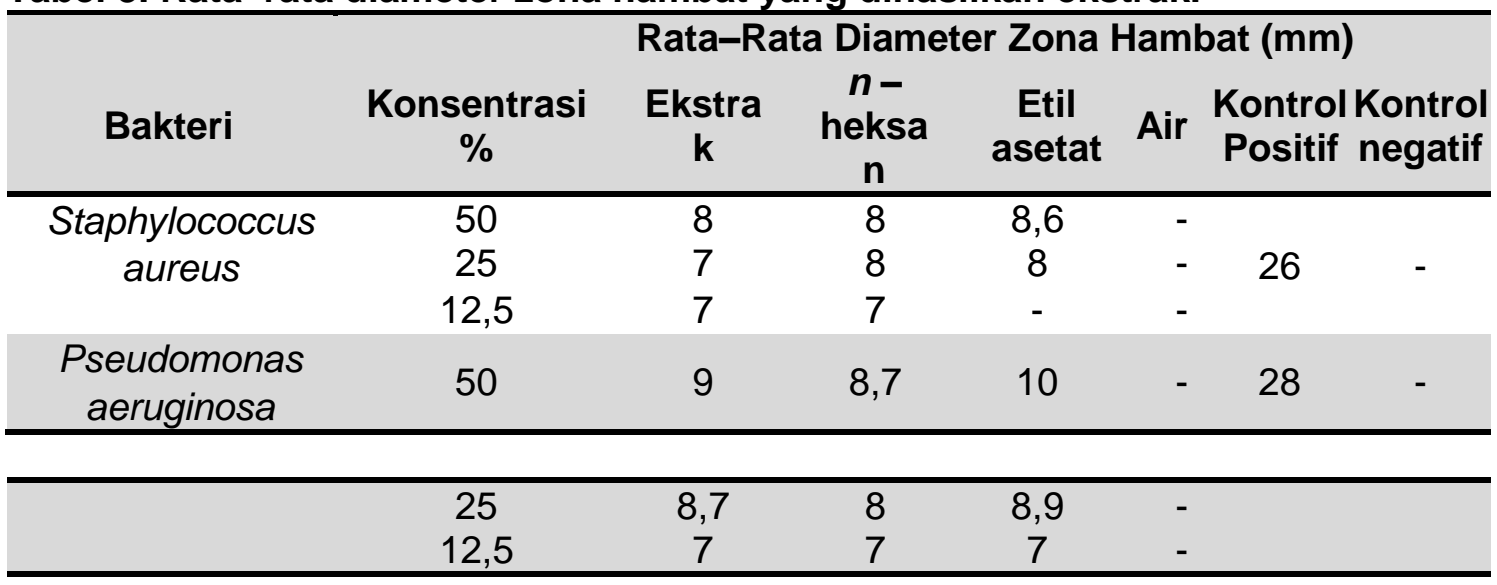
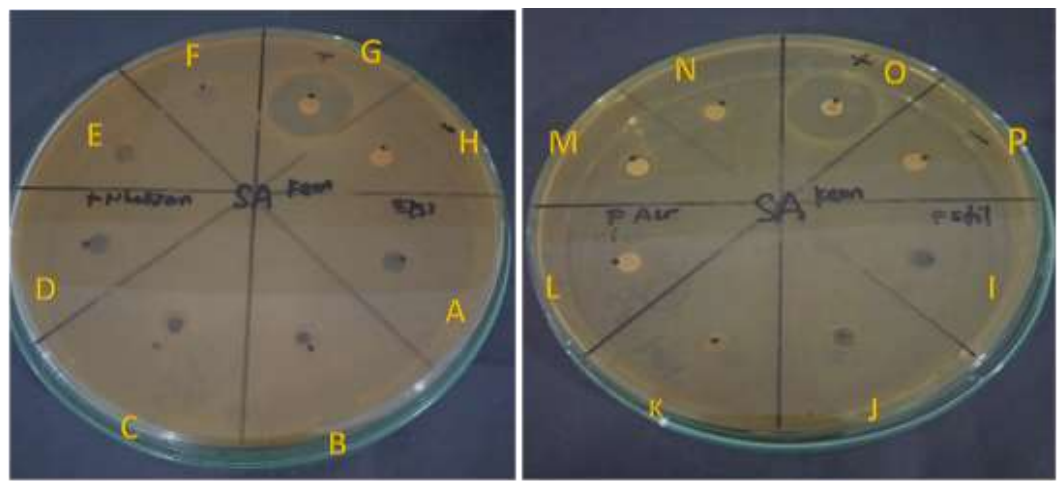

Gambar 1. Hasil Uji Aktivitas Antibakteri ekstrak Herba kemangi pada Staphylococcus aureus konsentrasi $50 \%$ (A), ekstrak 25\% (B), ekstrak $12,5 \%$ (C), Fraksi N-Heksan konsentrasi $50 \%(D), N$ Heksan 25\% (E), N-Heksan 12,5\% (F), Kontrol Positif Ciprofloxacin (G \& O), Kontrol Negatif tween 80 (H \& P), Fraksi Etil Asetat konsentrasi 50\% (I), Etil Asetat $25 \%$ (J), Etil Asetat 12,5\% (K), Fraksi Air Konsentrasi 50\% (L), Air 25\% (M), Air 12,5\% (N)
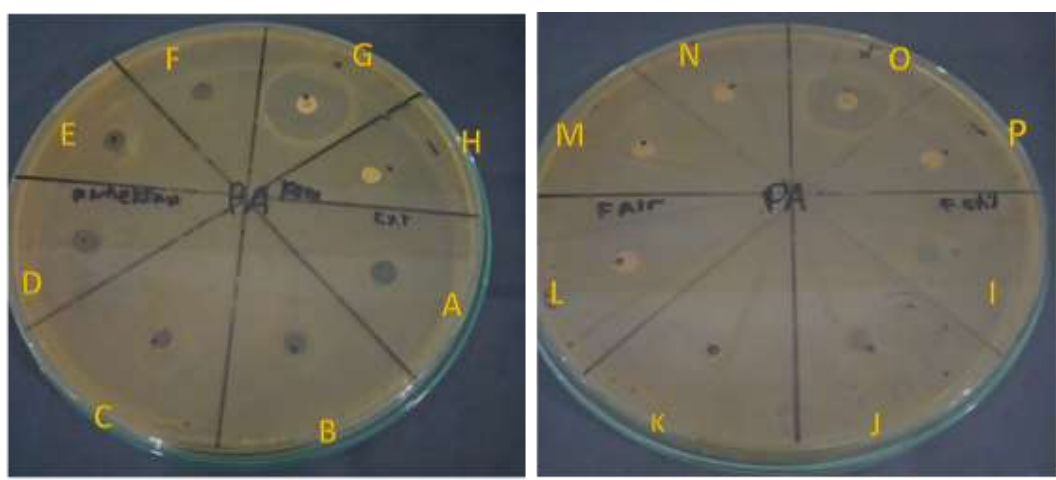

Gambar 2 Hasil Uji Aktivitas Antibakteri ekstrak Herba kemangi pada Pseudomonas aeruginosa konsentrasi $50 \%$ (A), ekstrak $25 \%$ (B), ekstrak 12,5\% (C), Fraksi $\mathrm{N}$-Heksan konsentrasi $50 \%(\mathrm{D}), \mathrm{N}$ Heksan 25\% (E), N-Heksan 12,5\% (F), Kontrol Positif Ciprofloxacin (G \& O), Kontrol Negatif tween 80 (H \& P), Fraksi Etil Asetat konsentrasi 50\% (I), Etil Asetat 25\% (J), Etil Asetat 12,5\% (K), Fraksi Air Konsentrasi 50\% (L), Air 25\% (M), Air 12,5\% (N) 
Hal ini disebabkan Pseudomonas aeruginosa merupakan bakteri Gram negatif dengan membran luar terdiri dari lipid, protein dan lipopolisakarida. Menurut Madduluri et al, 2013 senyawa yang dapat merusak membrane lipid, menyebabkan integritas membran menurun dan morfologi membran sel terganggu sehingga lisis dan rapuh salah satunya adalah senyawa steroid yang juga terkandung didalam fraksi kemangi.

Hasil Uji Aktivitas Antibakteri Dengan Metode Dilusi. Pada metode dilusi sampel yang digunakan adalah fraksi etil asetat karena pada fraksi ini yang memiliki daya hambat paling besar terhadap bakteri $S$ aureus ATCC 25923 dan $P$ aeruginosa ATCC 27853.

Kadar hambat minimum (KHM) fraksi etil asetat dibuat melalui seri konsentrasi dari $50 \%$ sampai $0,78 \%$ ditanamkan pada media cair yang berisi biakan bakteri $S$ aureus ATCC 25923 dan $P$ aeruginosa ATCC 27853 dan diinkubasi selama 24 jam.

Herba kemangi memiliki kadar hambat minimum pada bakteri $S$ aureus dan $P$ aeruginosa yang dilakukan menunjukan kadar hambat minimum masing-masing pada konsenrasi $12,5 \%$ terbukti dengan tidak berwarna keruh (tidak adanya endapan) pada tabung reaksi begitu pula pada kontrol negatifnya. Sedangkan konsentrasi $6,25 \%$ ke bawah menunjukan larutan berwarna keruh dan (memiliki endapan) sama dengan kontrol positif hasil dapat dilihat pada Tabel 4.

Pengujian KBM dilakukan dengan menanam kembali sediaan uji yang telah diketahui KHM-nya kedalam Nutrient agar tanpa senyawa uji selama 24 jam kemudian diamati ada atau tidaknya pertumbuhan bakteri. Dari hasil penelitian dapat dilihat bahwa konsentrasi bunuh minimum fraksi etil asetat herba kemangi terhadap bakteri $S$ aureus dan $P$ aeruginosa yang dilakukan dengan 2 kali replikasi. Kadar bunuh minimum (KBM) pada bakteri $S$ aureus pada konsenrasi $25 \%$ terbukti dengan tidak tumbuhnya bakteri dari hasil KHM yang di inokulasikan pada media Nutrient agar setelah diinkubasi selama 24 jam pada suhu $37^{\circ} \mathrm{C}$. sedangkan kadar bunuh minimum (KBM) pada $P$ aeruginosa pada konsentrasi $12,5 \%$. Hasil dapat dilihat pada Tabel 5.

Tabel 4. Kadar Hambat Minimum Fraksi Etil Asetat Herba Kemangi

\begin{tabular}{|c|c|c|c|c|c|c|c|c|c|}
\hline \multirow[b]{2}{*}{ Mikroba } & \multirow{2}{*}{$\begin{array}{c}\text { Kontro } \\
\text { I } \\
\text { Negatif }\end{array}$} & \multicolumn{7}{|c|}{$\begin{array}{l}\text { KHM Fraksi Etil Asetat Herba Kemangi } \\
\%\end{array}$} & \multirow{2}{*}{$\begin{array}{c}\text { Kontro } \\
\text { I } \\
\text { Positif }\end{array}$} \\
\hline & & 50 & 25 & $\begin{array}{c}12 \\
5\end{array}$ & $\begin{array}{c}6,2 \\
5\end{array}$ & 3,12 & $\begin{array}{c}1,5 \\
6\end{array}$ & 0,78 & \\
\hline s. aureus 1 & - & - & - & - & + & + & + & + & + \\
\hline s. aureus 2 & - & - & - & - & + & + & + & + & + \\
\hline $\begin{array}{l}P . \text { aeruginosa } \\
1\end{array}$ & - & - & - & - & + & + & + & + & + \\
\hline $\begin{array}{l}P . \text { aeruginosa } \\
2\end{array}$ & - & - & - & - & + & + & + & + & + \\
\hline
\end{tabular}


Tabel 5. Kadar bunuh minimum fraksi etil asetat herba kemangi

\begin{tabular}{|c|c|c|c|c|c|c|c|c|c|}
\hline \multirow[b]{2}{*}{ Mikroba } & \multirow{2}{*}{$\begin{array}{c}\text { Kontro } \\
\text { I } \\
\text { negatif }\end{array}$} & \multicolumn{7}{|c|}{ KBM fraksi etil asetat herba kemangi \% } & \multirow{2}{*}{$\begin{array}{c}\text { Kontro } \\
\text { I } \\
\text { Positif }\end{array}$} \\
\hline & & 50 & 25 & $\begin{array}{c}12 \\
5\end{array}$ & $\begin{array}{c}6,2 \\
5\end{array}$ & $\begin{array}{c}3,1 \\
2\end{array}$ & 1,56 & 0,78 & \\
\hline S. aureus 1 & - & - & - & + & + & + & + & + & + \\
\hline S. aureus 2 & - & - & - & + & + & + & + & + & + \\
\hline $\begin{array}{c}P . \text { aeruginosa } \\
1\end{array}$ & - & - & - & - & + & + & + & + & + \\
\hline $\begin{array}{l}P . \text { aeruginosa } \\
2\end{array}$ & - & - & - & - & + & + & + & + & + \\
\hline
\end{tabular}

\section{KESIMPULAN}

Ekstrak dan fraksi herba kemangi memiliki aktivitas antibakteri terhadap S. aureus ATCC 25923 dan $P$. aeruginosa ATCC 27853 dengan diameter zona hambat maksimal 10 $\mathrm{mm}$. Sedangkan fraksi etil asetat memiliki aktivitas antibakteri tertinggi dengan diameter daya hambat $10 \mathrm{~mm}$ terhadap bakteri $P$. aeruginosa dan 8,6 $\mathrm{mm}$ terhadap bakteri $S$. aureus pada konsentrasi $50 \%$. Fraksi etil asetat herba kemangi memiliki kadar hambat minimum KHM sebesar 12,5\% terhadap $S$. aureus ATCC 25923 dan $P$. aeruginosa ATCC 27853. Sedangkan fraksi etil asetat herba kemangi memiliki kadar bunuh minimum KBM sebesar 25\% terhadap S. aureus ATCC 25923 dan $12.5 \%$ terhadap $P$. aeruginosa ATCC 27853.

Ekstrak dan fraksi herba kemangi memiliki kandungan senyawa flavonoid, steroid dan saponin yang berperan dalam uji aktivitas bakteri $S$. aureus ATCC 25923 dan P. aeruginosa ATCC 27853.

\section{UCAPAN TERIMA KASIH}

Tim Peneliti menyampaikan banyak terima kasih kepada LPPM Universitas Setia Budi Surakarta yang telah mendanai penelitian ini sehingga penelitian ini bisa berjalan dengan baik dan bermanfaat bagi perkembangan ilmu pengetahuan.

\section{DAFTAR PUSTAKA}

Sarah SM dan Lamia A.M. 2015. Estimation of the phitochemical constituens and biological activity of iraqi Ocimum sanctum $L$. extracts. Int $J$ Pharm Bio Sci 2015 Jan.; 6(1): (B) 999-1007

Nur Atikah. 2013. Uji Aktivitas Antimikroba Ekstrak Herba Kemangi terhadap Staphylococcus aureus Skripsi Jakarta. Fakultas Farmasi Universitas Islam Negeri.

Kemenkes RI [Kementerian Kesehatan Republik Indonesia]. 2013 Farmakope Herbal Indonesia. Edisi I. Suplemen III. Jakarta: Kemenkes RI.

Harborne, J. B., 1987, Metode Fitokimia Penuntun Cara Modern Menganalisis Tumbuhan, Edisi kedua, Hal 5, 69-76, 
diterjemahkan oleh Kosasih Padmawinata dan Iwang Soedira, ITB Press, Bandung

Madduliri, Suresh, Rao, K. Babu. Sitram, B. 2013. In vitro evaluation of five Indegenous plants extract Againts five bacterial Phatogens of Human. International Journal of Pharmacy and Pharmaceutical Science 5(4): 679-684.

Noviyanti Y, P.P. Subur, dan T. Daniel. 2014. Uji Fitokimia, Toksisitas Dan Aktivitas Antibakteri Terhadap Ekstrak Etanol Daun Rambusa (Passiflora Foetida L.) Terhadap Bakteri Staphylococcus aureus Dan Escherichia coli. Jurnal Kimia Mulawarman Volume 12 Nomor 1. ISSN 1693-5616 Kimia FMIPA Unmul Kimia FMIPA Unmul 31

Jawetz, E., Melnick, J. L. dan Adelberg, E. A. 2007. Medical Microbiology 242 th Edition. Geo. F. Brooks, San Fransisco

Riska F, Puguh S, Sarwiyono, 2014, Inhibition Activityof Moringa oleifera Leaf Juice to Growth of Streptococcus agalactiae and Streptococcus uberis Bacteris Caused Mstitisin Dairy Cows, Jurnal, Fakultas Pertanian Universitas Brawijaya, Malang. 